\title{
Growth hormone, insulin-like growth factor system, and carcinogenesis
}

\author{
Oś hormon wzrostu-insulinopodobny czynnik wzrostu a karcynogeneza
}

\author{
Cesar Luiz Boguszewski', Margaret Cristina da Silva Boguszewski², John J. Kopchick ${ }^{3}$ \\ ${ }^{1}$ Department of Internal Medicine, Endocrine Division (SEMPR), Federal University of Paraná, Curitiba, Brazil \\ ${ }^{2}$ Department of Paediatrics, Endocrine Division (SEMPR), Federal University of Paraná, Curitiba, Brazil \\ ${ }^{3}$ Department of Biomedical Sciences, Heritage College of Osteopathic Medicine, Edison Biotechnology Institute, \\ Ohio University, Athens, USA
}

\begin{abstract}
The growth hormone (GH) and insulin-like growth factor (IGF) system plays an important role in the regulation of cell proliferation, differentiation, apoptosis, and angiogenesis. In terms of cell cycle regulation, the GH-IGF system induces signalling pathways for cell growth that compete with other signalling systems that result in cell death; thus the final effect of these opposed forces is critical for normal and abnormal cell growth. The association of the GH-IGF system with carcinogenesis has long been hypothesised, mainly based on in vitro studies and the use of a variety of animal models of human cancer, and also on epidemiological and clinical evidence in humans. While ample experimental evidence supports a role of the GH-IGF system in tumour promotion and progression, with several of its components being currently tested as central targets for cancer therapy, the strength of evidence from patients with acromegaly, GH deficiency, or treated with GH is much weaker. In this review, we will attempt to consolidate this data. (Endokrynol Pol 2016; 67 (4): 414-426)
\end{abstract}

Key words: growth hormone; insulin-like growth factor; cancer; carcinogenesis

\section{Streszczenie}

Oś hormon wzrostu (GH)-insulinopodobny czynnik wzrostu (IGF) odgrywa istotną rolę w regulacji proliferacji i różnicowania komórek, apoptozy i angiogenezy. Oś GH-IGF wpływa na regulację cyklu komórkowego przez pobudzenie szlaku wzrostu komórki w stosunku do szlaków sygnałowych prowadzących do śmierci komórki, a ostateczny efekt oddziaływania tych dwóch sił ma podstawowe znaczenie dla prawidłowego lub nieprawidłowego wzrostu komórki. Hipotezy na temat powiązań osi GH-IGF z karcynogenezą pojawiły się wiele lat temu, głównie w oparciu o wyniki badań in vitro oraz badań z wykorzystaniem różnych zwierzęcych modeli raka występującego u ludzi. Chociaż liczne dane doświadczalne potwierdzają rolę osi GH-IGF sprzyjającą rozwojowi i progresji nowotworów, a nad kilkoma składowymi tej osi trwają obecnie badania oceniające ich przydatność jako główne cele terapii przeciwnowotworowej, to jednak siła dowodów uzyskanych u chorych z akromegalią, niedoborem GH lub osób leczonych GH jest znacznie słabsza. W niniejszej pracy przeglądowej spróbowano zebrać wszystkie te dane. (Endokrynol Pol 2016; 67 (4): 414-426)

Słowa kluczowe: hormon wzrostu; insulinopodobny hormon wzrostu; rak; karcynogeneza

\section{Introduction}

Mechanisms controlling cell proliferation are dependent of a complex cascade of events that, when altered or disrupted, can lead to a substantial increase in the risk of carcinogenesis. The growth hormone $(\mathrm{GH})$ and insulin-like growth factor (IGF) system, which consists of GH, GH receptor (GHR), two growth factors (IGF-I and IGF-II), two cell surface receptors (IGF-IR and IGF-IIR), six binding proteins (IGFBPs), and a group of proteases, play a central role in the regulation of body growth and metabolic processes [1-5].
Growth hormone and IGFs have the ability to promote cell proliferation, differentiation, and angiogenesis, and they also inhibit apoptosis, potentially favouring tumour development. In contrast, other players of the IGF system, such as IGFBP-3, proteases, and IGFRs, have been shown to modulate IGF actions by inhibiting cell proliferation, stimulating apoptosis, and helping to determine cell survival. In turn, both circulating IGFBP-3 and IGF-I levels are dependent on and induced by GH. Consequently, the GH-IGF system induces signalling pathways for cell growth that compete with other signalling systems resulting 
in cell death. The final effect of these opposed forces in a tissue-specific environment is critical for normal and abnormal cell growth [1-5].

The association between the GH and IGF system and carcinogenesis has long been postulated based on experimental, epidemiological, and clinical data. In the 1950s, the potential role of GH in carcinogenesis was demonstrated by suppression of metastases development in hypophysectomised rats, resulting in attempts to treat advanced cancers in humans by surgical pituitary ablation [6, 7]. More recently, genome-wide association studies (GWAS) have identified GH-induced signalling pathways as the third highest pathway associated with breast cancer susceptibility, opening new therapeutic perspectives [8]. The preponderance of data suggests a slight increased risk of some cancers due to higher activity of the GH-IGF system and a protective effect against developing cancer in states of GH and IGF-I deficiencies. This article reviews the different sources of experimental human and animal studies, as well as the existing epidemiological and clinical data, implicating the GH and IGF system with cancer risk.

\section{GH and IGF system}

Pituitary GH secretion is pulsatile and mainly regulated by two hypothalamic peptides: GH-releasing hormone $(\mathrm{GHRH})$ and somatostatin. GHRH induces GH gene transcription and hormone release, while somatostatin suppresses both basal and GHRH-stimulated GH pulses. In addition, the stomach derived peptide ghrelin represents an additional stimulus for GH secretion, acting through the GH secretagogue (GHS) receptors expressed in somatotroph cells. After secretion, roughly $40-45 \%$ of circulating $\mathrm{GH}$ binds to a high-affinity $\mathrm{GH}$ binding protein (GHBP), which represents the extracellular domain of the GH receptor (GHR) [9]. GHRs are ubiquitously distributed and they are present as constitutive dimers in the cell membranes. GHR activation by $\mathrm{GH}$ binding results in structural rearrangements of the GHR that ultimately results in activation of JAK-2 and STAT-5, but can also trigger the mitogen-activated protein kinase (MAPK), Akt/phosphoinositide 3-kinase (PI3K), and other intracellular signalling pathways [10].

Growth hormone stimulates the production of IGF-I primarily by the liver, which is the major source of circulating IGF-I, IGFBPs, and, plausibly, IGF-II $[9,11]$. IGF-I is also produced in several other tissues in response to $\mathrm{GH}$ and exerts a negative feedback effect on $\mathrm{GH}$ secretion by stimulation of somatostatin release in the hypothalamus and inhibition of GH gene transcription in the pituitary. The IGFBPs comprise a superfamily of six proteins (IGFBP-1 to -6) that bind to IGFs with high affinity and specificity and a family of IGFBP-related proteins (IGFBP-rPs), which are structurally similar to the IGFBPs but bind IGFs with much lower affinity [5]. In plasma, most IGFs are associated with a high molecular weight complex (a ternary complex) consisting of IGFBP-3 and the acid labile subunit (ALS). Less than $1 \%$ of total IGF-1 is free. Circulating IGF-I levels rise during juvenile life and then decline after puberty, while circulating IGF-II levels are highest in the foetal circulation [11]. When the ternary complex dissociates, the binary complexes of IGFBP-IGF are removed from the circulation and cross the endothelium to reach the target tissues. The cellular responses to the IGFs are mediated by the IGF receptors, members of the tyrosine kinase growth factor family, and by IGFBPs, which modulate the ligand-receptor interaction by binding with higher affinity to the IGFs than the cognate receptors or by acting as a reservoir that can slowly release the ligands. IGFs and IGFBPs are also locally produced in many other tissues, where autocrine or paracrine mechanisms take place and where IGFs actions are also regulated by IGFBP proteases [2-5].

The IGF system comprises two main receptors (IGF-IR and IGF-IIR). IGF-IR is a hetero-tetramer formed by two identical $\alpha$-subunits and two identical $\beta$-subunits, exhibiting high homology with the insulin receptor (IR). In fact, IGF-I, IGF-II, and insulin can cross-bind to each other's receptor with much lower affinity than that observed for the authentic ligand. The homology between IGF-IR and IR permit the formation of hybrid receptors, composed of one $\alpha$-subunit and one $\beta$-subunit of each receptor, the amounts of which vary from tissue to tissue. These hybrid receptors have higher binding affinity for IGF-I than for insulin, and despite the fact that their biologic significance remains mostly unknown, it is thought that they function mainly as an IGF-IR, i.e. by activating downstream targets that lead to cellular proliferation $[4,5,11]$.

The mitogenic activity of the IGF-IR is mediated through the Ras and AKT pathways and results in the upregulation of Cyclin D and its binding partner CDK4. Under non-dividing cell conditions, retinoblastoma protein $(\mathrm{Rb})$ is bound with the E2F transcription factor. When CDK4 is activated and is bound with Cyclin $\mathrm{D}$, the Cyclin D/CDK4 complex phosphorylates $\mathrm{Rb}$ and E2F is released. The released E2F is then free to act as a transcription factor, activating expression of downstream target genes like Cyclin E [12]. The AKT pathway plays a critical role in apoptosis by inhibiting pro-apoptotic proteins like BAD and FKHR and activating anti-apoptotic factors such as NF-kappa B and MDM2. Moreover, IGF-IR activation downregulates cell cycle suppressors such as p27kip1, p57kip2, and PTEN. IGF receptors inducible pathways might share signalling crosstalk with other receptor/signalling systems, 
resulting in multiple interconnected pathways with important physiologic and therapeutic implications [4, 5].

IGF-IIR is a type I transmembrane glycoprotein with a large extracellular domain consisting of three ligand-binding regions: one for IGF-II and two for proteins containing mannose-6-phosphate (M6P) and the dormant form of transforming growth factor beta (TGF- $\beta$ ). For this reason, IGF-IIR is also called the IGF-II/M6P receptor. IGF-IIR exhibits structural and biochemical differences with IGF-IR and IR. Also, the extracellular domain of the IGF-IIR dissociates from the cell membrane as a soluble fragment, circulating in the blood with the ability to bind to IGF-II and facilitate its degradation. IGF-IIR does not transduce an intracellular signal, but rather acts to reduce the bioactivity of IGF-II by sequestering it away from the IGF-IR. Thus, in addition to IGFBPs, IGF-IIR provides extra control for the circulating levels of IGFs, functioning as a "sink" that controls the local bioavailability of IGF ligands for binding to the IGF-IR $[4,5,11]$. Figure 1 illustrates the relationship among the main components of the GHIGF system.

\section{Experimental evidence}

\section{In vitro studies}

GH, IGF-I, and their receptors have been identified in a variety of solid and haematological malignancies, including breast, prostate, brain, thyroid, pancreas, ovary, colorectal, and renal cancer cells, and their increased expression has been associated with poorer therapeutic response to radio- and chemotherapy [3, 4]. GH and IGFs might stimulate tumour growth by either direct effects on cell proliferation, differentiation, and survival or by synergy with other growth factors. In addition, IGFs have been shown to exhibit angiogenic properties and to be able to promote metastases. Neutralisation of IGF actions and disruption of the IGF-R-induced pathways have been tested as targets for novel cancer therapies [5].

The possibility of GH acting through an autocrine/ paracrine manner has been investigated in human endometrial carcinoma cell lines RL95-2 and AN3. These cell lines were stably transfected with a plasmid designed to express human GH (hGH) [13]. Both AN3vector (control cells) and AN3-hGH cell lines expressed equivalent levels of the GHR, while AN3-hGH secreted detectable levels of hGH into the culture medium. Compared to control AN3-vector-containing cells, the AN3-hGH cells grow significantly faster over a 14-day period and demonstrated enhanced anchorageindependent cell growth. Similar results were found with the RL95-2 cell line. In addition, antagonism of GH-induced signalling by B2036 (a GHR antagonist) resulted in reduction of cell oncogenic properties. These studies demonstrate a functional role for autocrine $\mathrm{GH}$ in the development and progression of endometrial carcinoma and indicate potential therapeutic relevance of GHR antagonism. Similar findings have recently been reported on oestrogen receptor (ER)-positive mammary carcinoma cells [14]. On the other hand, another study that investigated the role of the GH/IGF-I axis on glioma cell lines demonstrated that, even in the presence of a low GH/IGF-I environment, the growth of glioma tumour cells could not be inhibited in vivo, suggesting the involvement of other signals for cell proliferation [15]. In agreement, intracellular signalling 'crosstalk' pathways have been identified between IGF-IR and the erbB family of receptors, which include erbB1 (EGFR) and erbB2 (HER2/neu), in ovarian and breast cancer, and IGF-IR and ER in breast cancer [4]. These 'crosstalking' pathways might have important therapeutic implications, possibly contributing to drug resistance. Different strategies have been attempted to overcome this problem. For instance, dual therapy directed to different targets with IMC-A12 (anti-IGF-IR antibody) and cetuximab (anti-EGFR antibody) has been tested in head and neck cancer and with IMC-A12 and lapatinib (tyrosine-kinase inhibitor against HER2) in breast cancer [4].

IGFBPs have been shown to be synthesised in some malignant tissues, such as lung, breast, and ovarian cancers. They might impact carcinogenesis by several mechanisms, including regulation of bioavailability of IGFs in circulation and interactions with extracellular proteases that degrade IGFBPs and release ligand for subsequent receptor activation. Some proteolytic fragments, particularly of IGFBP-5, -4 , and -3 , may also exhibit ligand-independent biological activities [2-4]. The specific mechanisms by which IGFBPs affect tumour progression are more complex, and discrepant in vitro results have been described, depending on the experimental conditions and type of malignancy.

\section{Animal models: GH-IGF system excess}

Transgenic mice for human GH exhibit very high levels of GH in plasma and have an increased incidence of spontaneous mammary carcinomas. It has been demonstrated, however, that activation of the prolactin receptor, instead of the GHR, is important for induction of mammary tumours in these transgenic animals [16]. Overexpression of human IGF-I in epidermal cells and prostate epithelium in transgenic mice was shown to induce persistent epidermal hyperplasia, spontaneous skin tumour formation, and spontaneous prostate tumorigenesis $[17,18]$. The tumour-promoting effect of transgenic IGF-I may be independent of its binding to the IGFBPs [2]. This was suggested in mice overexpressing the transgene des-IGF-I, an IGF-I analogue with low affinity for IGFBP, which retains a high binding 


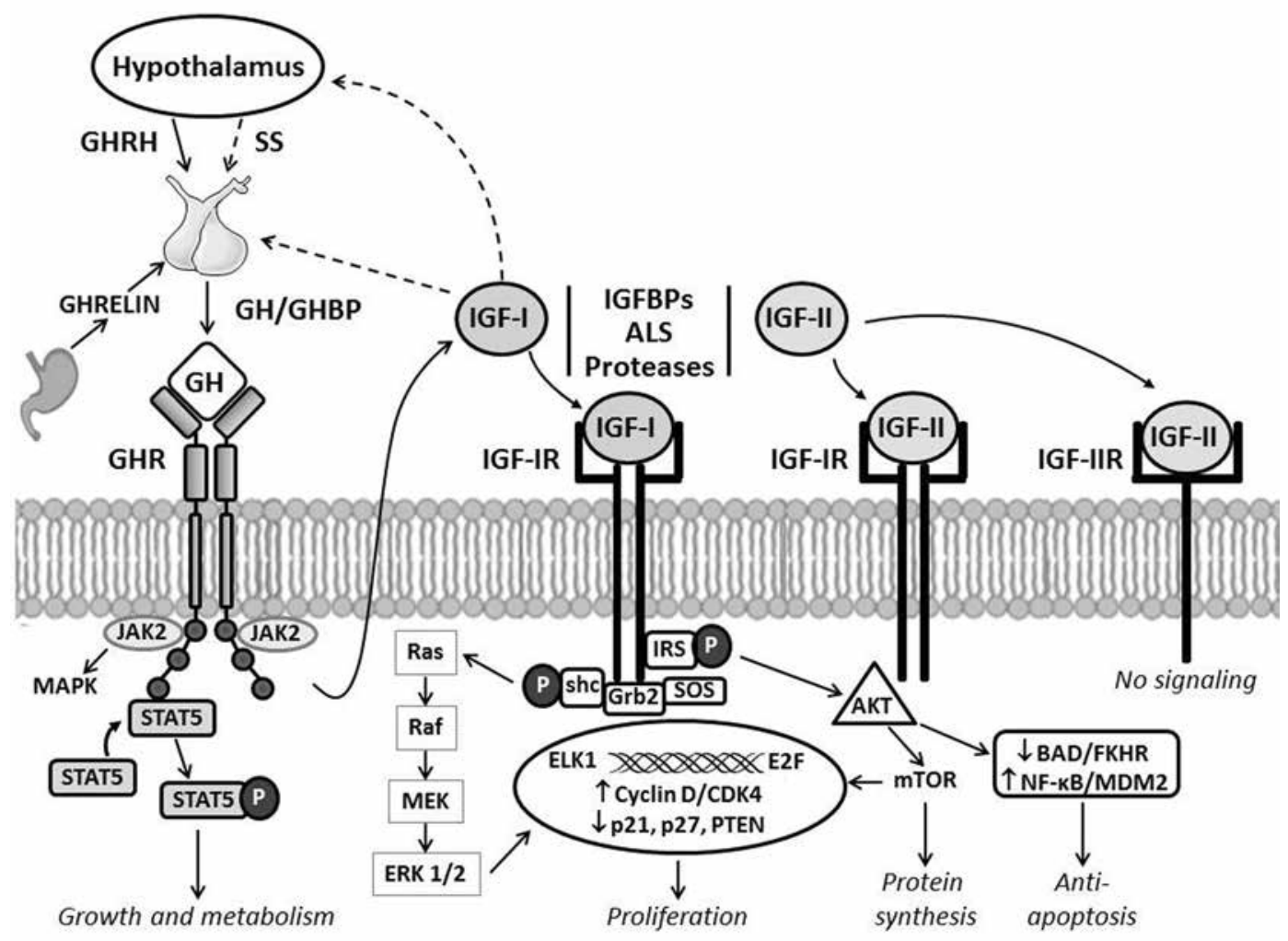

Figure 1. The GH-IGF system. Pituitary GH secretion is stimulated by GH-releasing hormone (GHRH), and ghrelin and is inhibited by somatostatin (SS) and by a negative feedback effect of IGF-I. Nearly half of GH circulates in blood bound to a high-affinity GH binding protein (GHBP). GH receptor (GHR) activation by GH binding results in activation of JAK-STAT proteins and can also trigger other mitogen signaling pathways. GH stimulates IGF-I production in the liver and in several tissues. In plasma, most IGF-I circulates in a ternary complex with IGFBP-3 and the acid labile subunit (ALS). IGBP-3 is a GH-dependent member of a family of six IGFBPs. Cellular responses to the IGF-I and IGF-II are mediated by two receptors (IGF-IR and IGF-IIR), by hybrid receptors formed with the insulin receptor (not shown in the figure), and by IGFBP proteases. The IGF-IIR does not transduce an intracellular signal, but rather acts to reduce the availability of IGF-II. The mitogenic activity of the IGF-IR is mainly mediated through the Ras and AKT pathway, while the later also plays a critical role in cell survival by inhibiting pro-apoptotic and activating anti-apoptotic factors

Rycina 1. Oś GH-IGF. Wydzielanie GH przez przysadkę jest stymulowane przez somatoliberyne (GH-releasing hormone, GHRH) oraz greline, a hamowane przez somatostatynę (SS) oraz sprzężenie zwrotne ujemne spowodowane przez IGF-I. Niemal połowa GH krąży we krwi w postaci związanej z białkiem wiążacym GH (GH binding protein, GHBP). Aktywacja receptora GH (GH receptor, GHR) przez związanie z GH powoduje aktywację białka JAK-STAT i może również uruchamiać inne mitogenne szlaki sygnatowe. GH stymuluje produkcję IGF-I w wątrobie i innych tkankach. W osoczu większość IGF-I występuje w postaci trójskładnikowego kompleksu z IGFBP-3 i podjednostki kwasolabilnej (acid labile subunit, ALS). Białko IGBP-3 jest GH-zależne i należy do rodziny sześciu biatek IGFBP. W odpowiedzi komórkowej na IGF-I i IGF-II pośredniczq dwa swoiste receptory (IGF-IR i IGF-IIR), hybrydowe receptory utworzone z receptorem insulinowym (nieprzedstawione na rycinie) oraz proteazy IGFBP. Receptor IGF-IIR nie przewodzi sygnałów wewnątrzkomórkowych, lecz powoduje zmniejszenie dostępności IGF-II. Aktywność mitogenna IGF-IR zależy głównie od aktywności szlaków Ras i AKT, przy czym ten drugi szlak ma kluczowe znaczenie dla przetrwania komórki, ponieważ hamuje czynniki proapoptotyczne i aktywuje czynniki o dziataniu antyapoptotycznym

affinity for IGF-IR [19]. Accordingly, IGF-II excess in transgenic animals has been linked to disproportionate body growth, increased size of thymus, skin, kidney, adrenal, and testis, and development of hepatocellular, mammary, lung, thyroid, and colonic carcinomas, as well as lymphomas and sarcomas [2, 3, 20-22].

IGF-IR overexpression in transgenic mice has been associated with increased rate of salivary, pancreatic, and mammary tumour formation [23, 24]. Moreover, upregulation of the IGF-IR signalling axis has been shown to drive the survival of prostate cancer cells in many studies [25]. Down-regulation of IGF-IR and its signalling pathways have been targeted for several types of anti-cancer therapies, including the use of antisense oligonucleotides, antisense RNA, small interfering RNA, triple helix-forming oligodeoxynucleotides, single chain antibody, fully humanised anti-IGF-IR monoclonal antibodies, and specific kinase inhibitors [2]. For instance, A12 (a human IGF-IR antibody) was combined with docetaxel in one study designed to investigate 
Table I. Tissue growth and tumour development in animal models with overexpression of individual components of the GHIGF system

Tabela I. Wzrost tkanek i rozwój nowotworów w modelach zwierzęcych z nadmiernq̨ ekspresją poszczególnych składowych osi GH-IGF

\begin{tabular}{lll}
\hline Excess & Model & Main findings \\
\hline GH & Overexpression of human GH in transgenic mice & Increased incidence of mammary tumours (by activation of PRL receptor) \\
\hline IGF-I & $\begin{array}{l}\text { Overexpression of human IGF-I in epidermal cells } \\
\text { and prostate epithelium of transgenic mice }\end{array}$ & $\begin{array}{l}\text { Persistent epidermal hyperplasia } \\
\text { Spontaneous skin tumour formation } \\
\text { Spontaneous prostate tumorigenesis }\end{array}$ \\
\hline IGF-II & $\begin{array}{l}\text { IGF-II loss of imprinting and overexpression of IGF-II } \\
\text { in mammary gland, liver, lung epithelium, skin, kidney, }\end{array}$ & $\begin{array}{l}\text { Disproportionate body growth } \\
\text { Increased size of thymus, skin, kidney, adrenal, and testis } \\
\text { Increased incidence of lymphomas, sarcomas and carcinomas } \\
\text { (hepatocellular, mammary, colonic, lung, and thyroid) }\end{array}$ \\
\hline IGF-IR & $\begin{array}{l}\text { Overexpression of IGF-IR in mammary, pancreatic } \\
\text { and salivary tissues of transgenic mice and upregulation } \\
\text { of IGF-IR signalling }\end{array}$ & $\begin{array}{l}\text { Increased rate of salivary, pancreatic, and mammary tumour formation } \\
\text { Increased survival of prostate cancer cells }\end{array}$ \\
\hline IGFBPs & $\begin{array}{l}\text { Gene transfer, upregulation or overexpression of IGFBPs } \\
\text { in transgenic animals }\end{array}$ & \begin{tabular}{l} 
Marked reduction or attenuation of tumour growth at different tissues \\
\hline
\end{tabular} \\
\hline
\end{tabular}

the effect of blocking IGF-I signalling on human androgen-independent and advanced prostate tumour growth [26]. The results showed that the inhibition of IGF-IR enhanced the therapeutic effect of docetaxel on advanced prostate cancer. However, a recent phase II randomised clinical trial in chemotherapy-naïve men with progressing castration-resistant prostate cancer treated with figitumumab (a human IgG2 monoclonal antibody targeting IGF-IR) did not corroborate these preliminary findings. In this study, patients received figitumumab every three weeks with docetaxel/prednisone (Arm A) or docetaxel/prednisone alone (Arm B1). At progression on Arm B1, patients could cross over to the combination (Arm B2). The primary endpoint, the prostate-specific antigen (PSA) response, did not improve significantly with figitumumab therapy. Nevertheless, a PSA response of $28 \%$ was observed in patients treated with the combination after disease progression with docetaxel/prednisone alone, suggesting that figitumumab might be more active post-docetaxel than in the docetaxel-naïve patients [27].

In contrast, overexpression of IGF-IIR and mutant IGF-IR molecules have been used to decrease the bioavailability of both IGF-II and IGF-I. For instance, the IGFIR $^{933}$ - a genetically engineered analogue derived from a mutated IGF1R consisting of the entire extracellular domain of the IGF-IR - was expressed in highly metastatic H-59 murine lung carcinoma cells and was shown to neutralise the effects of exogenous IGF-I, thus diminishing IGF-I-induced signalling and blocking IGF-I-mediated cellular functions such as cell proliferation, invasion, and survival [2]. More recently, an IGF-targeting protein named IGF-Trap, comprising a soluble form of human IGF-IR and the Fc portion of human IgG1, was developed. The IGF-Trap has a high affinity for human IGF-IR and IGF-IIR, but low affinity for insulin receptor, and can block IGF-IR signalling in several carcinoma cell types and inhibit tumour cell proliferation, migration, and invasion. In vivo, the IGF-Trap was shown to suppress growth of established breast carcinoma tumours, improving disease-free survival, and to promote markedly reduction of experimental liver metastasis of colon and lung carcinoma cells. The IGF-Trap demonstrated superior therapeutic efficacy in comparison with IGF-IR antibody, suggesting that it might overcome some limitations of current IGF-IRtargeting agents [28].

As demonstrated in Table I, while overexpression or constitutive activation of GH, IGFs and IGF-IR promotes carcinogenesis, experiments using gene transfer, upregulation, or overexpression of IGFBPs in transgenic animals have demonstrated marked reduction or attenuation of tumour growth at different tissues by decreasing the mitogenic activity of IGFs, and inducing apoptosis and/or inhibiting angiogenesis [2, 3]. In addition, the development of protease-resistant mutant IGFBPs, lacking the IGFBP protease cleavage sites, has also been investigated as potential anti-cancer therapy [5]. Pappalysin- 1 is a metalloproteinase encoded by the Pappa gene, responsible for the cleavage of IGFBP4 bound to IGF-I. In Pappa-/- mice, an abundance of IGFBP-4 and decreased bioavailability of IGF-I have been associated with a lower incidence of tumours and degenerative lesions, with an approximate six-month delay in ageing-related pathologies compared with WT mice $[29,30]$. 
Table II. Tumour development in animal models with deficiency in components of the GH-IGF system

Tabela II. Rozwój nowotworów w modelach zwierzęcych z niedoborem składowych osi GH-IGF

\begin{tabular}{|c|c|c|c|c|c|}
\hline $\begin{array}{l}\text { Animal } \\
\text { Model }\end{array}$ & Defect & GH & IGF-1 & $\begin{array}{l}\text { Tumour } \\
\text { incidence }\end{array}$ & $\begin{array}{l}\text { Main } \\
\text { Findings }\end{array}$ \\
\hline SDR & Inactivating mutation in the $\mathrm{GH}$ gene & $\downarrow$ & $\downarrow$ & $\downarrow$ & Mammary tumours if treated with GH \\
\hline lit/lit & Missense mutation in the GHRH-R gene & $\downarrow$ & $\downarrow$ & $\downarrow$ & $\begin{array}{l}\text { Resistance to chemical-induced tumorigenesis } \\
\text { Impaired growth of tumour xenografts }\end{array}$ \\
\hline $\begin{array}{l}\text { GHR-/- } \\
\text { (Laron mice) }\end{array}$ & GH receptor gene disruption & $\uparrow$ & $\downarrow$ & $\downarrow$ & Overall reduced occurrence of neoplasms \\
\hline GHA & $\begin{array}{l}\text { Expression of a mutated bovine GH gene exhibiting } \\
\text { a classic GHR antagonism action }\end{array}$ & $\uparrow$ & $\downarrow$ & $?$ & Protection from breast cancer development \\
\hline LID & Liver-specific deletion of the IGF-I gene & $\uparrow$ & $\downarrow$ & $\downarrow$ & $\begin{array}{l}\text { Marked inhibition of mammary and colonic } \\
\text { tumours and metastases }\end{array}$ \\
\hline
\end{tabular}

\section{Animal models: GH-IGF system deficiency}

Several mutations that decrease the tone of the GH/ IGF-1 axis are associated with protection from tumour development and extended longevity in animal models [31] (Table II). In Spontaneous Dwarf Rats (SDR), which have an inactivating mutation in the GH gene, investigations were conducted to assess $\mathrm{GH}$ action in the progression of mammary carcinogenesis [32-34]. They demonstrated that SDR rats treated with GH become vulnerable to mammary carcinogenesis and that these advanced rat mammary cancers are dependent on GH for their survival. Moreover, concomitant steroid treatment has been shown to block GH action, possibly by reducing serum IGF-I levels. Resistance to chemical-induced tumorigenesis and impaired growth of tumour xenografts have also been observed in lit/lit mice [35-37], which are GH and IGF deficient due to a missense mutation resulting in loss of function of the pituitary GHRH receptor (GHRH-R).

An overall reduced occurrence of neoplasms has been observed in GHR - / - mice throughout their lifespan [38-40]. In these animals, the tumour burden (number of different types of tumours) was reduced by $47 \%$ compared to WT mice. As for the cause of death, $83 \%$ of WT mice die from neoplastic disease while only $42 \%$ (49\% reduction) of the GHR - / - mice die from such lesions. The GHR-/- mouse model has also been used to examine the role of the GH/IGF-I axis in mammary [41] and prostate carcinogenesis [42]. It has been found that the disruption of the GH/IGF-I axis significantly retards TAg-driven mammary carcinogenesis in oestrogenindependent breast cancer and confers resistance to prostate carcinogenesis. Additionally, a study utilising the GH antagonist (GHA) mouse model demonstrated that inhibition of the $\mathrm{GH}$ action could provide striking protection from breast cancer in vivo [43].
The above studies, as well as many confirming in vitro data, argue for the use of the GHR antagonist (pegvisomant) for selected cancers [44]. In an early study, pegvisomant was examined for its impact on cancer cell xenografts in athymic nude mice [45]. Treatment of WT $\mathrm{FVB} / \mathrm{N}$ mice with pegvisomant severely reduced mammary development and reduced GH and IGF-I signalling in mammary glands. The ability of pegvisomant to inhibit cancer growth was also investigated in human colorectal carcinoma cell lines in nude mice [46]. In this study, Colo205 and HT-29 cell xenographs were grown in nude mice until they reached a volume of $90-105 \mathrm{~mm}^{3}$ and $60-70 \mathrm{~mm}^{3}$, respectively. The mice were then separated into two groups and injected every other day with either saline or pegvisomant at $60 \mathrm{mg} / \mathrm{kg}$. After 16 days of injections, pegvisomant treatment caused a 39\% reduction in tumour volume and a $44 \%$ reduction in tumour weight in the nude mice with the COLO 205 colorectal cancer. However, pegvisomant had no effect on the HT-29 colorectal cancer, suggesting that the inhibition of GH/IGF-I may represent a treatment for some colorectal cancers. In a third study, a direct blockade of the GHR by pegvisomant was suggested to contribute to reduce meningioma growth and, in some instances, to promote tumour regression [47].

IGF-I knockout mice have severe developmental abnormalities and most do not survive, making it difficult to study how genetic ablation of IGF-I affects tumorigenesis. However, studies have been done in a mice models containing a liver-specific deletion of the IGF-I gene that results in a 50-75\% reduction in circulating IGF-1 levels associated with high GH levels. In agreement with other models of GH deficiency, these liver-specific IGF-I deficient (LID) mice exhibit a marked inhibition of colonic and mammary tumorigenesis and metastases [48, 49]. 


\section{Human studies}

\section{Epidemiological data}

There is evidence of a real, albeit weak, association between height and cancer risk, with taller individuals appearing to be at increased risk for a range of cancers. Geographic patterns of cancer incidence and mortality have been associated with variations in population height, particularly in relation to breast, colon, and prostate cancer $[50,51]$. A systematic review including 300 cohorts or nested case-control studies depicting the association of height and cancer found a significant increase in the incidence of colon, breast, and prostate cancer in taller individuals. Leg length was more often associated with increased risk than trunk length [52]. Recent meta-analyses have also confirmed a positive association between height and ovarian, pancreatic, and kidney cancer risk [53-55]. It has been speculated that these findings may be partly mediated through IGF pathways, as genetic damage accumulation might be facilitated in taller individuals with IGF-I levels in the upper limits of the normal range due to increased rate of cell division and reduced apoptosis [56]. Strikingly, recent genome-wide SNP-association studies have identified several human height-associated genes that have also been linked to neoplastic growth and higher risk for cancer [57].

A large number of prospective epidemiological studies have found that high serum IGF-I levels (when the highest quartile is compared with the lowest, within the normal range) and/or lower levels of IGFBPs (when the lowest quartile is compared with the highest, within the normal range) are associated with increased risk for neoplasia at different sites, including breast, prostate, lung, colorectal, endometrial, thyroid, and bladder cancer $[2,58]$. A summary of meta-analyses linking circulating levels of IGF-I and IGFBP-3 with the incidence of the four most prevalent cancers in Western populations was published some years ago [3]. This study found that high circulating levels of IGF-I were positively associated with increased risk of prostate, breast (both in pre- and postmenopausal women) and colorectal cancer. Also, the lower circulating IGFBP-3 levels were weakly associated with risks of prostate and breast cancer in postmenopausal women. However, the associations between IGFBP-3 and cancer risk disappeared when adjustment for IGF-1 levels took place. A recent investigation involving 385,747 participants from 23 centres of 10 European countries found that IGF-I concentrations were positively associated with risk of differentiated thyroid carcinoma [58] (Fig. 2). Higher levels of circulating IGF-I have also been linked to an increased incidence of precancerous colonic adenoma (large or tubulovillous/villous) and cervical squamous intraepithelial lesions, suggesting a role for the IGF-I system in the early stages of transformation and carcinogenesis $[2,59,60]$.

IGF-I gene polymorphisms, especially the allele containing CA19 repeats, have been associated with the risk for various types of cancers. A recent metaanalysis, however, concluded that such polymorphisms are unlikely to be a major determinant of susceptibility to cancer, although in a subgroup analysis of a recessive model, the authors found that CA19 repeats may reduce the risk of certain types of cancer or may influence the risk in specific populations [61].

Loss of imprinting (LOI), an epigenetic alteration in the IGF-II gene that results in bi-allelic expression of IGF-II, has been reported in a variety of tumours, including Ewing sarcoma, rhabdomyosarcoma, Wilms' tumour, clear cell sarcoma, renal cell carcinoma, malignant glioma, and a variety of gynaecological and testicular neoplasms [11]. Moreover, LOI of IGF-II gene has been identified as an individual risk factor for developing colorectal carcinoma and, more recently, with poor prognosis of patients with oesophageal squamous cell carcinoma $[2,11,62,63]$. LOI can be assayed with a DNA-based blood test, and it has been proposed as a predictive marker of an individual's risk for colorectal cancer $[2,11,62]$.

\section{Cancer on states of GH and IGF-I deficiency}

Several mutations in the gene encoding for GHRH receptor (GHRHR) have been found in distinct populations, most of them showing a recessive mode of inheritance. The phenotype includes reduced, but not absent, serum GH, and low IGF-I levels, resulting in proportionate growth failure, which becomes evident in the first year of life $[31,64]$. The largest cohort of patients with dwarfism caused by homozygous GHRHR mutations comprises more than 100 individuals from Itabaianinha, a rural area in the north-eastern Brazilian State of Sergipe [65]. As expected, all individuals have severe GH and IGF-I deficiencies, and their adult heights vary from $105 \mathrm{~cm}$ to $135 \mathrm{~cm}$. The risk of death in this dwarf population is not different from that observed in their unaffected siblings, and there is no significant difference in life span between affected subjects, unaffected siblings, or the general population when the analysis is done for subjects who have reached age 20 years. In contrast, the life span is shorter than in the general population in females due to early deaths seen in those aged 4-20 years, mostly from diarrheal diseases. One death from cancer was observed in a subset of nine patients with dwarfism, which implies that the number of cancer-related deaths is unchanged compared to that in the general population $[31,65]$. 


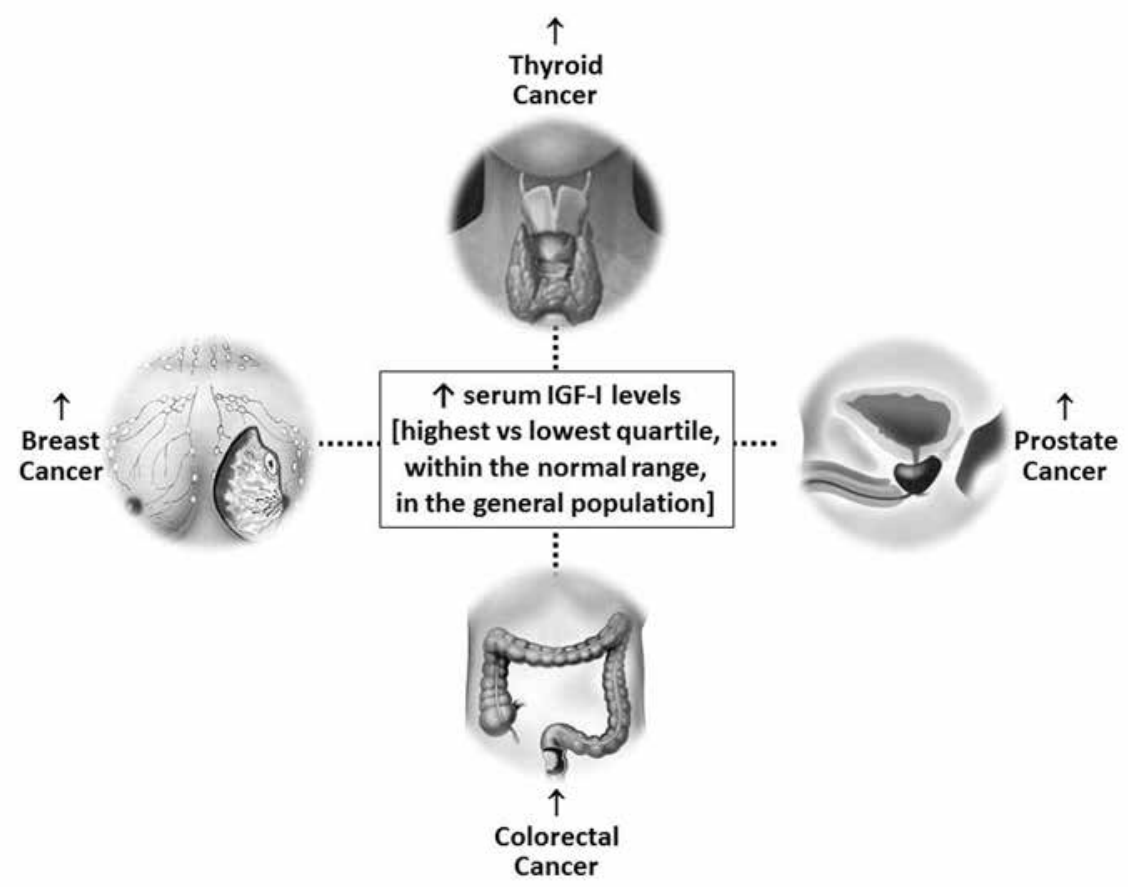

Figure 2. Epidemiological data linking serum IGF-I levels and cancer risk. Several prospective studies in the general population and meta-analyses have found an association between high serum IGF-I levels (when the highest quartile is compared with the lowest, within the normal range) with increased risk for prostate, breast (both in pre-and postmenopausal women), colorectal, and differentiated thyroid cancer. The associations between serum IGFBP-3 levels and cancer risk are weaker and usually disappear when adjustment for IGF-1 levels is performed

Rycina 2. Dane epidemiologiczne wiążace stężenie IGF-I w surowicy z ryzykiem rozwoju nowotworu. W kilku prospektywnych badaniach prowadzonych $w$ populacji ogólnej oraz metaanalizach wykazano związek między wysokim stężeniem IGF-I w surowicy (kiedy porównano najwyższy kwartyl z najniższym w zakresie wartości prawidtowych) ze zwiększonym ryzykiem raka prostaty, raka piersi (u kobiet w okresie przed- i pomenopauzalnym), raka jelita grubego i zróżnicowanego raka tarczycy. Zależności między stężeniem IGFBP-3 w surowicy a ryzykiem rozwoju nowotworu są stabe i zwykle znikaja po skorygowaniu względem stężenia IGF-1

Another important observation implicating GH and IGF actions in human cancer came from 2 cohorts of Laron individuals, who present an inactivating mutation within their GHR gene, and as such, are IGF-I deficient due to insensitivity to GH action. In one cohort of 230 Laron patients, none of the individuals developed cancer [66]. In a second cohort located in Ecuador, out of a population of 99 Laron patients, only one patient exhibited a non-lethal malignancy, in contrast to a $17 \%$ cancer incidence in control individuals [67]. In this study, the authors were able to show that serum from Laron subjects reduced DNA breaks but increased apoptosis in human mammary epithelial cells (HMECs) treated with hydrogen peroxide. They also observed that affected individuals had increased insulin sensitivity in relation to unaffected relatives. Thus, there is an extraordinary and exciting reduction in the incidence of cancer in Laron Syndrome patients, in agreement with the findings in the Laron mice (GHR-/-) pointed out above, which exhibit a dwarf phenotype with low levels of IGF-1 and reduced rates of cancer [31, 38-40].

\section{Cancer in Acromegaly}

Acromegaly is a rare disease typically caused by a GHsecreting pituitary adenoma, that represents the best human model to understand the consequences of a continuous and prolonged exposure to high GH and IGF-I concentrations [68]. The overall mortality rate is higher in patients with active acromegaly, mainly due to vascular and respiratory diseases, whereas normalisation of GH and IGF-I levels is accompanied by reduction of mortality rate compared to that of the normal population $[69,70]$. Retrospective mortality studies have shown that, on average, $15-24 \%$ of deaths in acromegaly are attributable to cancer, with particular focus on colorectal cancer (CRC) and, to a lesser extent, on breast, thyroid, prostate and other cancers [71]. However, the question of whether cancer risk is increased in acromegaly is still under debate [72-74]. There are many problems and limitations in quantifying risk of cancer in patients harbouring a rare disease. Most studies include small numbers of individuals, with no statistical 
power to adjust the data for confounding factors, such as age and gender. The comparison between older and more recent occurrences of the disease is challenging because both cancer incidence in the general population and life expectancy in patients with acromegaly have dramatically changed over the past few decades, influencing the prevalence of disease-associated morbidities. In fact, recent series have found cancer as a common cause of death and an independent predictor of mortality in acromegaly [75-78]. In addition, population-based cancer registries and epidemiology may vary from site to site. Another source of biases is the heterogeneity of comparative control populations used in the studies, which have varied from data published in literature to hospitalised non-acromegaly patients, matched-controls, or the general population $[73,74]$. Finally, the influence of acromegaly-associated morbidities in cancer and mortality risk is another point of interest. Obesity and diabetes are associated with an increased incidence and mortality from several types of malignancies in the general population [79]. There are several potential factors to explain the link between obesity, diabetes, and cancer, including insulin resistance, hyperinsulinaemia, high IGF-1, hyperglycaemia, dyslipidaemia, and abnormalities of gut microbiome [79]. Remarkably, these factors might also be present in acromegaly and contribute to increased risk of cancer. In one study, an increase in fasting insulin levels was associated with an 8.6- to 14.8-fold increased risk of colonic adenomas in acromegaly [80]. In another recent study from three Canadian referral centres involving 408 cases, acromegaly patients with diabetes developed malignant tumours almost three times as frequently as those without diabetes [81]. To date, most investigators would agree that if the risk of cancer is increased in acromegaly, the magnitude of this association is modest, and might be clinically relevant only for colorectal adenocarcinomas [71, 82, 83].

\section{$\mathrm{GH}$ therapy and cancer risk}

Recombinant human GH (rhGH) has been used in the last 30 years to treat children with GH deficiency and short stature caused by multiple disorders, and adult patients with severe GH deficiency. There have been a substantial number of publications dedicated to longterm surveillance for potential morbidities, including cancer development, in individuals being treated or previously exposed to rhGH. The vast experience from many thousands of patient-years of treatment has assured a good safety profile for rhGH in children and adults $[3,72,84]$. Despite most favourable evidence, there are still reports on possible unfavourable outcomes. Recently, the French Safety and Appropriateness of Growth Hormone treatments in Europe (SAGhE), a study carried out to evaluate the long-term mortality of a population-based cohort of patients treated with rhGH in childhood in France, found increased mortality rates in adults treated as children with rhGH, particularly in those who received the highest doses. In relation to neoplasia, all type cancer-related mortality was not increased, but a specific effect was detected for bone tumours [85]. However, this was represented by 3 cases of bone neoplasms vs. 0.6 expected in more than 6500 individuals with a $95 \%$ confidence interval ranging from 1.01-14.61. The results of the French cohort have not been reproduced elsewhere. The SAGhE report from Sweden, Belgium, and The Netherlands, including a total number of person-years of observation of 46.556, identified only 21 deaths in the cohort: 12 due to accidents, four due to suicides, and single cases of pneumonia, endocrine dysfunction, primary cardiomyopathy, deficiency of humoral immunity, and coagulation defect. Remarkably, there was no death from cancer or cardiovascular disease [86].

The constant need to address the long-term safety of rhGH treatment was the main motivation for the European Society of Paediatric Endocrinology (ESPE), the Growth Hormone Research Society (GRS), and the Paediatric Endocrine Society (PES) to convene an international meeting in 2014, which resulted in the publication of a concise position statement [87]. The document has addressed important issues related to rhGH therapy and cancer risk, as summarised in Table III. First, the available data in children and adults do not indicate an increased risk of new primary cancers in rhGH recipients. It pointed out, however, some limitations for definitive long-term conclusions in this topic, including the heterogeneity of information sources, inadequate sample sizes to assess cancers with low incidence, lack of appropriate comparison populations, and small number of subjects with long duration of follow-up. Second, available data in children do not indicate an increased risk of recurrence of primary cancer in rhGH recipients. In adults, data are insufficient to fully address this question, but it was highlighted that available data on benign pituitary tumours do not indicate an increased risk of recurrence during long-term rhGH therapy. The third issue addressed was the risk of second tumours in GH-treated survivors of paediatric cancers. In one study population, the highest risk was observed early after rhGH treatment, declining with longer follow-up [88]. In contrast, a more recent report from the Childhood Cancer Survivor Study failed to demonstrate an increased occurrence of second tumours in the brain associated with rhGH exposure [89]. Thus, the position document considered this potential risk insufficient to preclude the use of rhGH for licensed indications in chil- 
Table III. Summary of the main issues addressed by position statement published on behalf of the European Society of Paediatric Endocrinology (ESPE), the Growth Hormone Research Society (GRS), and the Paediatric Endocrine Society (PES) related to recombinant human GH (rhGH) therapy and cancer risk (Allen et al, 2015)

Tabela III. Podsumowanie najważniejszych problemów uwzględnionych w publikacji przedstawiajq̨cej wspólne stanowisko European Society of Paediatric Endocrinology (ESPE), Growth Hormone Research Society (GRS oraz Pediatric Endocrine Society (PES) dotyczq̨e wptywu leczenia rekombinowanym ludzkim czynnikiem wzrostu (recombinant human GH, rhGH) na ryzyko rozwoju nowotworu (Allen i wsp., 2015)

\begin{tabular}{lll}
\hline Observation & Conclusions & Remarks \\
\hline New primary cancer & Not increased in children and adults & $\begin{array}{l}\text { Heterogeneity of information sources } \\
\text { Inadequate sample size } \\
\text { Lack of appropriate control populations } \\
\end{array}$ \\
& & Small number of subjects with long duration of follow-up \\
\hline Recurrence of primary neoplasia & $\begin{array}{l}\text { Not increased in children } \\
\text { Insufficient data in adults } \\
\text { (no indication of increase) }\end{array}$ & \\
\hline $\begin{array}{l}\text { Second tumours in survivors } \\
\text { of cancer }\end{array}$ & $\begin{array}{l}\text { Conflicting data in } \\
\text { children-onset malignancy } \\
\text { Insufficient data in } \\
\text { adult-onset malignancy }\end{array}$ & $\begin{array}{l}\text { Potential risk insufficient to preclude the use of rhGH for licensed } \\
\text { indications in children } \\
\text { Issue should be discussed with patients and families }\end{array}$ \\
\hline 'High-risk' groups & Lack of definitive data & $\begin{array}{l}\text { Decision to start rhGH should be carefully considered and discussed } \\
\text { with families }\end{array}$ \\
\hline
\end{tabular}

dren, but made a recommendation to discuss this possibility with patients and their families [87]. In patients surviving adult-onset malignancies, data were not sufficient to reach a conclusion. Regarding the appropriate interval between completion of cancer therapy and initiation of rhGH in both children and adults, the position recommended taking into consideration factors related to the tumour, time elapsed since completion of cancer treatment, and the importance of initiating rhGH treatment in an individual patient (e.g. severity of growth failure if patient remains untreated). Finally, the position document stated that definitive data are lacking regarding the safety of rhGH therapy in 'highrisk' patients, in particular children with syndromes, diseases, and mutations known to be associated with an inherent elevated risk for cancer and early mortality (e.g. Neurofibromatosis type 1, Fanconi anaemia, or Down syndrome). In these clinical situations, the authors recommended that the decision to start therapy should be carefully considered and discussed with families [87].

\section{General considerations on GH and IGF system as a target for cancer therapy}

As previously mentioned, inhibition of GH action and IGF-I synthesis by pegvisomant, neutralisation of IGF actions, and/or blocking of IGF-IR (as well as hybrid receptors) and their signalling pathways are important targets in cancer research (Fig. 3). Many components of the IGF system have also been implicated in resistance to anti-cancer therapies with hormonal agents, radiation, and chemotherapy. Therapeutic strategies targeting the GH and IGF system have involved different types of cancer with variable degrees of success. High-affinity antibodies are in early developmental stage with the aim to neutralise both IGF-I and IGF-II, thus inhibiting IGF signalling via IGF-IR and hybrid receptors $[5,90]$. These receptors and their corresponding signalling pathways are currently the most important therapeutic targets of the IGF system. Several clinical trials have evaluated the efficacy of IGF-IR inhibition to induce anti-proliferative effects on IGF-signallingdependent tumours or to overcome the resistance mechanisms. Small molecule tyrosine kinase inhibitors (TKIs), anti-IGF-IR antibodies, and molecular agents, such as antisense and small interfering RNAs (si-RNAs), have been extensively investigated, but the optimal strategy is still not clear. The efficacy of these agents depends on several factors such as the expression and pathological importance of IGF-IR in the tumours, potency of inhibition, timing of use, toxicity, concomitant therapies, and compensation by other signalling pathways $[2,4,5]$. The modest benefits reported thus far underscore the need for a better understanding of the complexity of the IGF system and its interaction with other pathways. It is worth mentioning that all trials with anti-IGF-IR antibodies alone have failed, with several patients developing diabetes during treatment. Thus, a promising alternative approach is to co-target IGF-IR along with other pathways known to promote tumorigenesis. Examples of such a strategy include monoclonal antibodies and TKIs targeting simultane- 


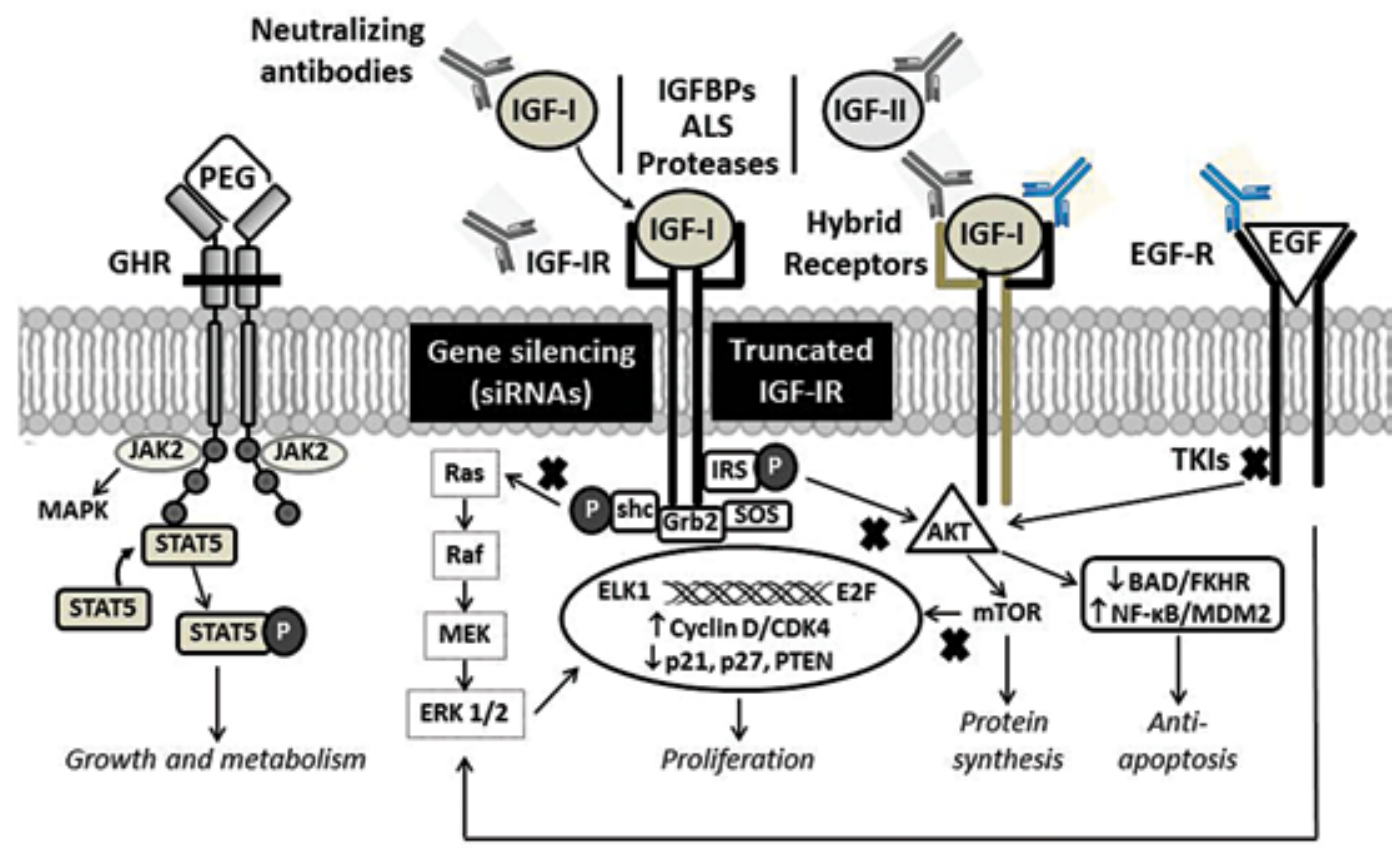

Figure 3. The GH-IGF system as target for cancer therapy. Main therapeutic strategies targeting GH-IGF system involve inhibition of GH action and IGF-I synthesis by pegvisomant, high-affinity antibodies against IGFs, IGF-IR, and IGF-I/insulin hybrid receptors, antibodies co-targeting IGF-1R along with other mitogenic pathways, such as epidermal growth factor receptor (EGFR), expression of truncated IGF-IR, tyrosine kinase inhibitors (TKIs), and gene silencing by small interfering RNAs (si-RNAs)

Rycina 3. Oś GH-IGF jest celem terapii przeciwnowotworowej. Najważniejsze strategie terapeutyczne ukierunkowane na oś GH-IGF obejmują hamowanie działania GH oraz syntezy IGF-I przez pegwisomant, białka o wysokim powinowactwie wobec IGF, IGF-IR i IGF-I/ hybrydowym receptorom insulinowym, przeciwciała ukierunkowane zarówno na IGF-1R, jak i szlaki mitogenne, np. receptor czynnika wzrostu naskórka (epidermal growth factor receptor, EGFR), ekspresję niepetnej formy IGF-IR, inhibitory kinazy tyrozynowej (tyrosine kinase inhibitors, TKI) oraz wyciszanie genów przez małe interferujace fragmenty RNA (si-RNA)

ously IGF-1R and epidermal growth factor receptor (EGFR) [5]. In view of current knowledge, future strategies for cancer therapy involving the GH and IGF system would need to be individualised considering not only histologic diagnosis but the nature of the perturbed intracellular signalling pathways.

\section{References}

1. Cohen P, Clemmons DR, Rosenfeld RG. Does the GH-IGF axis play a role in cancer pathogenesis? Growth Horm IGF Res 2000; 10: 297-305.

2. Samani AA, Yakar S, LeRoith D, Brodt P. The role of the IGF system in cancer growth and metastasis: overview and recent insights. Endocr Rev 2007; 28: 20-47.

3. Clayton PE, Banerjee I, Murray PG, Renehan AG. Growth hormone, the insulin-like growth factor axis, insulin and cancer risk. Nat Rev Endocrinol 2011; 7: 11-24.

4. Weroha SJ, Haluska P. The insulin-like growth factor system in cancer. Endocrinol Metab Clin North Am 2012; 41: 335-350.

5. Brahmkhatri VP, Prasanna C, Atreya HS. Insulin-like growth factor system in cancer: novel targeted therapies. Biomed Res Int 2015: 538019.

6. Pearson OH, Ray BS. Results of hypophysectomy in the treatment of metastatic mammary carcinoma. Cancer 1959; 12: 85-92.

7. Moseley HS, Peetz ME, Keenan EJ et al. Endocrine ablation for metastatic breast cancer: a reappraisal of hormone receptors. Am J Surg 1980; 140: 164-172.

8. Menashe I, Maeder D, Garcia-Closas Met al. Pathway analysis of breast cancer genome-wide association study highlights three pathways and one canonical signaling cascade. Cancer Res 2010; 70: 4453-4459.

9. Boguszewski CL. Molecular heterogeneity of human GH: from basic research to clinical implications. J Endocrinol Invest 2003; 26: 274-288.

10. Waters MJ, Brooks AJ. JAK2 activation by growth hormone and other cytokines. Biochem J 2015; 466: 1-11.
11. Bergman D, Halje M, Nordin $\mathrm{M}$ et al. Insulin-like growth factor 2 in development and disease: a mini-review. Gerontology 2013; 59: 240-249.

12. SenguptaS,Henry RW. Regulation of the retinoblastoma-E2F pathway by the ubiquitin-proteasome system. Biochim Biophys Acta 2015; 1849: 1289-1297.

13. Pandey V, Perry JK, Mohankumar KM et al. Autocrine human growth hormone stimulates oncogenicity of endometrial carcinoma cells. Endocrinology 2008; 149: 3909-3919.

14. Chen YJ, Zhang X, Wu ZS et al. Autocrine human growth hormone stimulates the tumor initiating capacity and metastasis of estrogen receptor-negative mammary carcinoma cells. Cancer Lett 2015; 365: 182-189.

15. Friend KE, Khandwala HM, Flyvbjerg A et al. Growth hormone and insulin-like growth factor-I: effects on the growth of glioma cell lines. Growth Horm IGF Res 2001; 11: 84-91.

16. Wennbo H, Gebre-Medhin M, Gritli-Linde A et al. Activation of the prolactin receptor but not the growth hormone receptor is important for induction of mammary tumors in transgenic mice. J Clin Invest 1997; 100: 2744-2751.

17. DiGiovanni J, Kiguchi K, Frijhoff A et al. Deregulated expression of insulin-like growth factor 1 in prostate epithelium leads to neoplasia in transgenic mice. Proc Natl Acad Sci USA 2000; 97: 3455-3460.

18. Wilker E, Lu J, Rho O et al. Role of PI3K/Akt signaling in insulin-like growth factor-1 (IGF-1) skin tumor promotion. Mol Carcinog 2005; 44: 137-145

19. Hadsell DL, Murphy KL, Bonnette SG et al. Cooperative interaction between mutant p53 and des(1-3)IGF-I accelerates mammary tumorigenesis. Oncogene 2000; 19: 889-898.

20. Ward A, Bates P, Fisher R et al. Disproportionate growth in mice with Igf-2 transgenes. Proc Natl Acad Sci USA 1994; 91: 10365-10369.

21. Bates P, Fisher R, Ward A et al. Mammary cancer in transgenic mice expressing insulin-like growth factor II (IGF-II). Br J Cancer 1995; 72: 1189-1193.

22. Wolf E, Hoeflich A, Lahm H. What is the function of IGF-II in postnatal life? Answers from transgenic mouse models. Growth Horm IGF Res 1998; 8: 185-193.

23. Carboni JM, Lee AV, Hadsell DL et al. Tumor development by transgenic expression of a constitutively active insulin-like growth factor I receptor. Cancer Res 2005; $65: 3781-3787$. 
24. Lopez T, Hanahan D. Elevated levels of IGF-1 receptor convey invasive and metastatic capability in a mouse model of pancreatic islet tumorigenesis. Cancer Cell 2002; 1: 339-353.

25. Wu J, Yu E. Insulin-like growth factor receptor-1 (IGF-IR) as a targe for prostate cancer therapy. Cancer Metastasis Rev 2014; 33: 607-617.

26. Wu JD, Haugk K, Coleman I et al. Combined in vivo effect of A12, a type 1 insulin-like growth factor receptor antibody, and docetaxel against prostate cancer tumors. Clin Cancer Res 2006; 12: 6153-6160.

27. de Bono JS, Piulats JM, Pandha HS et al. Phase II randomized study of figitumumab plus docetaxel and docetaxel alone with crossover for metastatic castration-resistant prostate cancer. Clin Cancer Res 2014 20: $1925-1934$

28. Wang N, Rayes RF, Elahi SM et al. The IGF-Trap: Novel Inhibitor of Carcinoma Growth and Metastasis. Mol Cancer Ther 2015; 14: 982-993.

29. Junnila RK, List EO, Berryman DE et al. The GH/IGF-1 axis in ageing and longevity. Nat Rev Endocrinol 2013; 9: 366-376.

30. Conover CA. Role of PAPP-A in aging and age-related disease. Exp Gerontol 2013; 48: 612-613.

31. Swanson SM, Unterman TG. The growth hormone-deficient Spontaneous Dwarf rat is resistant to chemically induced mammary carcinogenesis. Carcinogenesis 2002; 23: 977-982.

32. Thordarson G, Semaan S, Low C et al. Mammary tumorigenesis in growth hormone deficient spontaneous dwarf rats; effects of hormonal treatments. Breast Cancer Res Treat 2004; 87: 277-290.

33. Shen $\mathrm{Q}$, Lantvit DD, Lin $\mathrm{Q}$ et al. Advanced rat mammary cancers are growth hormone dependent. Endocrinology 2007; 148: 4536-4544.

34. Yang XF, Beamer WG, Huynh $\mathrm{H}$ et al. Reduced growth of human breast cancer xenografts in hosts homozygous for the lit mutation. Cancer Res 1996; 56: 1509-1511.

35. Deitel K, Dantzer D, Ferguson P et al. Reduced growth of human sarcoma xenografts in hosts homozygous for the lit mutation. J Surg Oncol 2002; 81: 75-79.

36. Takahara K, Tearle H, Ghaffari M et al. Human prostate cancer xenografts in lit/lit mice exhibit reduced growth and androgen-independent progression. Prostate 2011; 71: 525-537.

37. Zhou Y, Xu BC, Maheshwari HG et al. A mammalian model for Laron syndrome produced by targeted disruption of the mouse growth hormone receptor/binding protein gene (the Laron mouse). Proc Natl Acad Sci USA 1997; 94: 13215-13220.

38. List EO, Sackmann-Sala L, Berryman DE et al. Endocrine parameters and phenotypes of the growth hormone receptor gene disrupted (GHR-/-) mouse. Endocr Rev 2011:32:356-386.

39. Ikeno Y, Hubbard GB, Lee S et al. Reduced incidence and delayed occurrence of fatal neoplastic diseases in growth hormone receptor/binding protein knockout mice. J Gerontol A Biol Sci Med Sci 2009; 64: 522-529.

40. Zhang X, Mehta RG, Lantvit DD et al. Inhibition of estrogen-independent mammary carcinogenesis by disruption of growth hormone signaling. Carcinogenesis 2007; 28: 143-150.

41. Wang Z, Prins GS, Coschigano KT et al. Disruption of growth hormone signaling retards early stages of prostate carcinogenesis in the C3(1)/T antigen mouse. Endocrinology 2005; 146: 5188-5196.

42. Pollak M, Blouin MJ, Zhang JC et al. Reduced mammary gland carcinogenesis in transgenic mice expressing a growth hormone antagonist. B J Cancer 2001; 85: 428-430.

43. Kopchick JJ, Parkinson C, Stevens EC et al. Growth hormone receptor antagonists: discovery, development, and use in patients with acromegaly. Endocr Rev 2002; 23: 623-646.

44. Divisova J, Kuiatse I, Lazard Z et al. The growth hormone receptor antagonist pegvisomant blocks both mammary gland developmen and MCF-7 breast cancer xenograft growth. Breast Cancer Res Treat 2006; 98: 315-327.

45. Dagnaes-Hansen F, Duan H, Rasmussen LM et al. Growth hormone receptor antagonist administration inhibits growth of human colorectal carcinoma in nude mice. Anticancer Res 2004; 24: 3735-3742.

46. McCutcheon IE, Flyvbjerg A, Hill $\mathrm{H}$ et al. Antitumor activity of the growth hormone receptor antagonist pegvisomant against human meningiomas in nude mice. J Neurosurg 2001; 94: 487-492.

47. Olivo-Marston SE, Hursting SD, Lavigne J et al. Genetic reduction of circulating insulin-like growth factor-1 inhibits azoxymethane-induced colon tumorigenesis in mice. Mol Carcinog 2009; 48: 1071-1076.

48. Wu Y, Cui K, Miyoshi K et al. Reduced circulating insulin-like growth factor I levels delay the onset of chemically and genetically induced mammary tumors. Cancer Res 2003; 63: 4384-4388.

49. Albanes D, Taylor PR. International differences in body height and weight and their relationship to cancer incidence. Nutr Cancer 1990; 14: 69-77.

50. Andersson SO, Wolk A, Bergström R et al. Body size and prostate cancer: a 20 -year follow-up study among 135006 Swedish construction workers. J Natl Cancer Inst 1997; 89: 385-389.

51. Gunnell D, Okasha M, Smith GD et al. Height, leg length, and cance risk: a systematic review. Epidemiol Rev 2001; 23: 313-342.
52. Liang S, Lv G, Chen W et al. Height and kidney cancer risk: a meta-analysis of prospective studies. J Cancer Res Clin Oncol 2015; 141: 1799-1807.

53. Aune D, Vieira AR, Chan DS et al. Height and pancreatic cancer risk a systematic review and meta-analysis of cohort studies. Cancer Causes Control 2012; 23: 1213-1222.

54. Schouten LJ, Rivera C, Hunter DJ et al. Height, body mass index, and ovarian cancer: a pooled analysis of 12 cohort studies. Cancer Epidemiol Biomarkers Prev 2008; 17: 902-912.

55. Pollak MN, Schernhammer ES, Hankinson SE. Insulin-like growth factors and neoplasia. Nat Rev Cancer 2004; 4: 505-518.

56. Tripaldi R, Stuppia L, Alberti S. Human height genes and cancer. Biochim Biophys Acta 2013; 1836: 27-41.

57. Schmidt JA, Allen NE, Almquist $\mathrm{M}$ et al. Insulin-like growth factor-i and risk of differentiated thyroid carcinoma in the European prospective investigation into cancer and nutrition. Cancer Epidemiol Biomarkers Prev 2014; 23: 976-985.

58. Giovannucci E, PollakMN, Platz EA et al. A prospective study of plasma insulin-like growth factor-1 and binding protein-3 and risk of colorectal neoplasia in women. Cancer Epidemiol Biomarkers Prev 2000; 9: 345-349.

59. Wu X, Tortolero-Luna G, Zhao H, Phatak D, Spitz MR, Follen M. Serum levels of insulin-like growth factor I and risk of squamous intraepithelial lesions of the cervix. Clin Cancer Res 2003; 9: 3356-3361.

60. Guo Q, Shen F, Zhang C et al. IGF-I CA19 repeat polymorphisms and cancer risk: a meta-analysis. Int J Clin Exp Med 2015; 8: 20596-20602.

61. Cui H, Cruz-Correa M, Giardiello FM et al. Loss of IGF2 imprinting a potential marker of colorectal cancer risk. Science 2003; 299: 1753-1755.

62. Murata A, Baba Y, Watanabe M et al. IGF2 DMR0 methylation, loss of imprinting, and patient prognosis in esophageal squamous cell carcinoma. Ann Surg Oncol 2014; 21: 1166-1174.

63. Corazzini V, Salvatori R. Molecular and clinical aspects of GHRH receptor mutations. Endocr Dev 2013; 24: 106-117.

64. Aguiar-Oliveira MH, Oliveira FT, Pereira RM et al. Longevity in untreated congenital growth hormone deficiency due to a homozygous mutation in the GHRH receptor gene. J Clin Endocrinol Metab 2010; 95: 714-721.

65. Kopchick JJ, List EO, Kelder B et al. Evaluation of growth hormone $(\mathrm{GH})$ action in mice: discovery of GH receptor antagonists and clinical indications. Mol Cell Endocrinol 2014; 386: 34-45.

66. Steuerman R, Shevah O, Laron Z. Congenital IGF1 deficiency tends to confer protection against post-natal development of malignancies. Eur J Endocrinol 2011; 164: 485-489.

67. Guevara-Aguirre I, Balasubramanian P, Guevara-Aguirre M et al. Growth hormone receptor deficiency is associated with a major reduction in pro-aging signaling, cancer, and diabetes in humans. Sci Transl Med 2011; 3: 70ra13.

68. Bolanowski M, Ruchała M, Zgliczyński W et al Acromegaly: a novel view of the patient. Polish proposals for diagnostic and therapeutic procedures in the light of recent reports. Endokrynol Pol 2014; 65: 326-331.

69. Capatina C, Wass JA. 60 years of Neuroendocrinology: acromegaly J Endocrinol 2015; 226: 141-160.

70. Holdaway IM, Bolland MJ, Gamble GD. A meta-analysis of the effect of lowering serum levels of GH and IGF-I on mortality in acromegaly. Eur J Endocrinol 2008; 159: 89-95.

71. Loeper S, Ezzat S. Acromegaly: re-thinking the cancer risk. Rev Endocr Metab Disord 2008; 9: 41-58

72. Renehan AG, Brennan BM. Acromegaly, growth hormone and cancer risk. Best Pract Res Clin Endocrinol Metab 2008; 22: 639-657.

73. Melmed S. Acromegaly and cancer: not a problem? J Clin Endocrino Metab 2001; 86: 2929-2934.

74. Jenkins PJ, Besser M. Clinical perspective: acromegaly and cancer: a problem. J Clin Endocrinol Metab 2001; 86: 2935-2941.

75. Mercado M, Gonzalez B, Vargas G et al. Successful mortality reduction and control of comorbidities in patients with acromegaly followed at a highly specialized multidisciplinary clinic. J Clin Endocrinol Metab 2014; 99: 4438-4446.

76. Arosio M, Reimondo G, Malchiodi E et al. Predictors of morbidity and mortality in acromegaly: an Italian survey. Eur J Endocrinol 2012; 167: 189-198

77. Wen-Ko C, Szu-Tah C, Feng-Hsuan L et al. The impact of diabetes mellitus on the survival of patients with acromegaly. Endokrynol Pol 2016. DOI: 10.5603/EP.a2016.0031. Epub ahead of print

78. Ritvonen E, Löyttyniemi E, Jaatinen P et al. Mortality in acromegaly: a 20-year follow-up study. Endocr Relat Cancer 2015; 23: 469-480.

79. Gallagher EJ, LeRoith D. Epidemiology and molecular mechanisms tying obesity, diabetes, and the metabolic syndrome with cancer. Diabetes Care 2013; 36 (Suppl. 2): S233-239.

80. Colao A, Pivonello R, Auriemma RS et al. The association of fasting insulin concentrations and colonic neoplasms in acromegaly: a colonoscopy-based study in 210 patients. J Clinical Endocrinol Metab 2007; 92: 3854-3860.

81. Cheng S, Gomez K, Serri O et al. The role of diabetes in acromegaly associated neoplasia. PLoS One 2015; 10: e0127276. 
82. Boguszewski CL, Ayuk J. Acromegaly and cancer: an old debate revisited. Eur J Endocrinol. 2016. pii: EJE-16-0178. [Epub ahead of print]

83. Katznelson L, Laws ER Jr, Melmed S et al. Acromegaly: an Endocrine Society clinical practice guideline. J Clin Endocrinol Metab 2014; 99: 3933-3951.

84. Stochholm K, Johannsson G. Reviewing the safety of GH replacement therapy in adults. Growth Horm IGF Res 2015; 25: 149-157.

85. Carel JC, Ecosse E, Landier F et al. Long-term mortality after recombinant growth hormone treatment for isolated growth hormone deficiency or childhood short stature: preliminary report of the French SAGhE study. J Clin Endocrinol Metab 2012; 97: 416-425.

86. Sävendahl L, Maes M, Albertsson-Wikland Ket al. Long-term mortality and causes of death in isolated GHD, ISS, and SGA patients treated with recombinant growth hormone during childhood in Belgium, The Netherlands, and Sweden: preliminary report of 3 countries participating in the EU SAGhE study. J Clin Endocrinol Metab 2012; 97: E213-E217.

87. Allen DB, Backeljauw P, Bidlingmaier M et al. GH safety workshop position paper: a critical appraisal of recombinant human GH therapy in children and adults. Eur J Endocrinol 2015; 174: P1-9.

88. Ergun-Longmire B, Mertens AC, Mitby P et al. Growth hormone treatment and risk of second neoplasms in the childhood cancer survivor J Clin Endocrinol Metab 2006; 91: 3494-3498.

89. Patterson BC, Chen Y, Sklar CA et al. Growth hormone exposure as a risk factor for the development of subsequent neoplasms of the central nervous system: a report from the childhood cancer survivor study. J Clin Endocrinol Metab 2014; 99: 2030-2037.

90. Gao J, Chesebrough JW, Cartlidge SA et al. Dual IGF-I/II-neutralizing antibody MEDI-573 potently inhibits IGF signaling and tumor growth. Cancer Res 2011; 71: 1029-1040. 